\title{
Judicial Understanding of the Reliability of Eyewitness Evidence: A Tale of Two Cases
}

\section{Meintjes-van der Walt*}

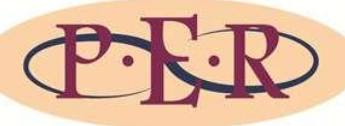

Author

Lirieka Meintjes van der Walt

Affiliation

Fort Hare University, South Africa

Email

LMeintjes-VanderWalt@ufh.ac.za

Date published 10 June 2016

Editor Prof S du Toit

How to cite this article

Meintjes van der Walt $L$ " Judicial Understanding of the Reliability of Eyewitness Evidence: A Tale of Two Cases" PER / PELJ 2016(19) - DOI

http://dx.doi.org/10.17159/17273781/2016/v19i0a11601247

\section{Copyright}

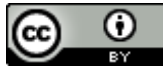

This work is licensed under a Creative Commons Attribution 4.0 International License.

DOI

http://dx.doi.org/10.17159/1727-

3781/2016/v19i0a1247

\section{Abstract}

One of the most significant consequences of the use of postconviction DNA testing in the criminal justice system has been the growing recognition that eyewitness identification testimony is simply not as reliable as it was previously considered to be. In approximately $75 \%$ of DNA exonerations in the United States, mistaken eyewitness identifications were the principal cause of wrongful convictions. Notwithstanding scientific advances regarding human memory and other factors that could influence identifications by eyewitnesses, courts have not shown eagerness in utilising such scientific knowledge in reaching legal decisions. Two cases have been chosen for discussion in this article. In S v Henderson 27 A 3d 872 (NJ 2011) the New Jersey Supreme Court was the first in State and Federal jurisdictions in the US that adopted a science-based approach to the evaluation of eyewitness evidence. The other case under discussion is $S$ v Mdlongwa 20102 SACR 419 (SCA), a South African Supreme Court of Appeal judgment, where the identification of the perpetrator was based on an eyewitness account and the evidence of an expert on CCTV images. In part one of this article the research findings with regard to estimator variables that were acknowledged in $S v$ Henderson are discussed. Part two specifically scrutinizes $S v$ Mdlongwa to determine the extent to which psychological eyewitness research findings are recognised in South Africa as having an influence on the reliability of eyewitness evidence. In Henderson the court recognised that the legal standards governing the admissibility and use of identification evidence lagged far behind the findings of numerous studies in the social sciences. The new wave introduced by $S v$ Henderson has not gone unnoticed in other State courts in the USA. In Massachusetts, for example, the Justices of the Supreme Judicial Court convened a study group on Eyewitness Evidence and the resulting report inter alia recommended judicial notice of modern psychological principles, revised jury eyewitness identification instructions and continuous education of both judges and lawyers. Recognition and education pertaining to these factors can and should be incorporated in South Africa.

\section{Keywords}

Eyewitness evidence; wrongful conviction; reliability of evidence; psychological eyewitness research findings; estimator variables. 


\section{Introduction}

\subsection{The frailties of eyewitness evidence}

The identification of the perpetrator is often the only issue that needs to be determined in a criminal trial. ${ }^{1}$ Eyewitness evidence is usually the main type of evidence on which convictions are based. One of the most significant consequences of the use of post-conviction DNA testing in the criminal justice system has been the growing recognition that eyewitness identification testimony is simply not as reliable as it was previously considered to be. In approximately $75 \%$ of DNA exonerations in the United States, mistaken eyewitness identifications were the principal cause of wrongful convictions. ${ }^{2}$ The actual impact of the problem is difficult to fathom as other offences such as robbery also involve eyewitness testimony but usually lack evidence that can be tested for DNA. ${ }^{3}$ Mistaken convictions of the innocent undermine the criminal justice system as a whole, because an innocent person is punished for a crime he or she did not commit, while the actual perpetrator continues to threaten society by remaining free. ${ }^{4}$ It would be naïve to believe that these difficulties are limited to overseas jurisdictions, and that the South African legal system does not face the same dilemma.

\subsection{Recognition of scientific research on eyewitness identification}

Psychologists raised doubts regarding the reliability of eyewitness accounts long before DNA testing became a reality. In the first part of the twentieth century, Hugo Münsterberg ${ }^{5}$ argued that the insights of psychology could assist legal decision making in cases where eyewitness statements have to be evaluated. ${ }^{6}$ However, it was only after the mid-1970s ${ }^{7}$ that psychologists started systematic experimental work regarding the margins of error and the variables involved in testimony presented by witnesses who had observed a crime. Throughout the last thirty years a considerable body of research has developed in the field of eyewitness identification. ${ }^{8}$ Social science

\footnotetext{
Lirieka Meintjes van der Walt. B Juris LLB (UPE) LLM (Rhodes) LLD (Rijksuniversiteit Leiden). Adjunct Professor of Law, Fort Hare University; Advocate of the High Court of South Africa. Email: LMeintjes-VanderWalt@ufh.ac.za

$S$ v Mdlongwa 20102 SACR 419 (SCA).

Monroe 2013 http://bit.ly/1TwThG0.

Findley "Wrongful Conviction."

Wyss Visual Identification 2.

Münsterberg On the Witness Stand.

Wells, Memon and Penrod 2006 Psychol Sci Public Interest 45.

Wells, Memon and Penrod 2006 Psychol Sci Public Interest 45.

Shell 2013 Suffolk U L Rev 263.
} 
research indicates a variety of causes of eyewitness misidentification. The scientific eyewitness identification literature tends to rely on a distinction between estimator variables and system variables. ${ }^{9}$ Estimator variables are those that affect the accuracy of eyewitness identifications, but cannot be controlled by the criminal justice system. ${ }^{10}$ System variables also affect the accuracy of eyewitness identifications, but the criminal justice system can control those variables. ${ }^{11}$ Estimator variables tend to have to do with situational factors involved in the acquisition phase, such as lighting conditions, distance, arousal, the presence of weapons, et cetera that cannot be addressed by systemic reform. ${ }^{12}$

However, notwithstanding scientific advances regarding human memory and other factors that could influence identifications by eyewitnesses, courts have not shown eagerness in utilising such scientific knowledge in reaching legal decisions. ${ }^{13}$ In some instances courts have grasped the effect that some variables have on decision-making ${ }^{14}$ and at other times decision makers have neglected to take note of research results that can assist the trier of fact in evaluating eyewitness evidence. ${ }^{15}$

\subsection{A comparative view}

The question of how to incorporate the scientific findings into judicial decision-making in order to prevent some of the major problems attached to eyewitness evidence has been enduring. ${ }^{16}$ In some states in the United States of America (USA), expert evidence has been allowed to educate the jury, but courts have resisted this approach as it is an expensive and timeconsuming method to manage the problem. ${ }^{17}$ In South Africa expert evidence on the frailties of eyewitness evidence is unlikely to be admitted on the basis that the modalities of eyewitness evidence are regarded as common sense which lies within the knowledge of the presiding officer. Moreover, in respect of eyewitness testimony it is frequently believed that

Wells $1978 \mathrm{~J}$ Pers Soc Psychol 1548.

Wells 1978 J Pers Soc Psychol 1548-1552.

Wells $1978 \mathrm{~J}$ Pers Soc Psychol 1552.

Wells 1978 J Pers Soc Psychol 1552-1555.

Harris Failed Evidence; Meintjes-Van der Walt 2009 SACJ 305-326.

$14 \quad R \vee$ Masemang 19502 SA 488 (A) 493: "The often patent honesty, sincerity and conviction of an identifying witness remains, however, a snare to the judicial officer who does not constantly remind himself of the necessity of dissipating any danger of error in such evidence."

15 Meintjes-Van der Walt 2009 SACJ 305-326.

16 Meintjes-Van der Walt 2009 SACJ 305-326.

17 See Penrod and Cutler 1995 Behav Sci \& L 229, 230; Leippe 1995 Psychol Pub Pol'y \& $L 909$. 
any unreliability can be exposed by cross-examination. ${ }^{18}$ What this view does not consider is that some factors bearing on the reliability of eyewitness identification may be contrary to the intuitive beliefs of most people, and that cross-examination is not sufficient a tool to expose identity errors made by an honest but mistaken witness.

Two cases have been chosen for discussion and analysis below. In $S v$ Henderson, ${ }^{19}$ the New Jersey Supreme Court was the first in State and Federal jurisdictions in the US that adopted a science-based approach to the evaluation of eyewitness evidence. The other case under discussion is $S v$ Mdlongwa ${ }^{20}$ a South African Supreme Court of Appeal judgment, where the identification of the perpetrator was based on an eyewitness account and the evidence of an expert on CCTV images. ${ }^{21}$ This case is used as a barometer to measure the extent to which estimator variable factors could influence eyewitness identification in South Africa. It is not contended that the decision in $S v$ Mdlongwa was necessarily incorrect, but the Mdlongwa22 judgment is used to reflect the differences between the two cases in respect of eyewitness testimony and the recognition of eyewitness science.

In part one of this article the research findings with regard to estimator variables ${ }^{23}$ that were acknowledged in $S v$ Henderson are discussed. Part two specifically scrutinises the South African Supreme Court of Appeal judgment in $S v$ Mdlongwa $^{24}$ to determine the extent to which psychological eyewitness research findings are recognised in South Africa as having an influence on the reliability of eyewitness evidence.

\section{S v Henderson 27 A 3d 872 (NJ 2011) 25}

2.1 The background In $S v$ Henderson ${ }^{26}$ New Jersey's highest court unanimously revisited its thirty-four-year-old legal standard as applied in the

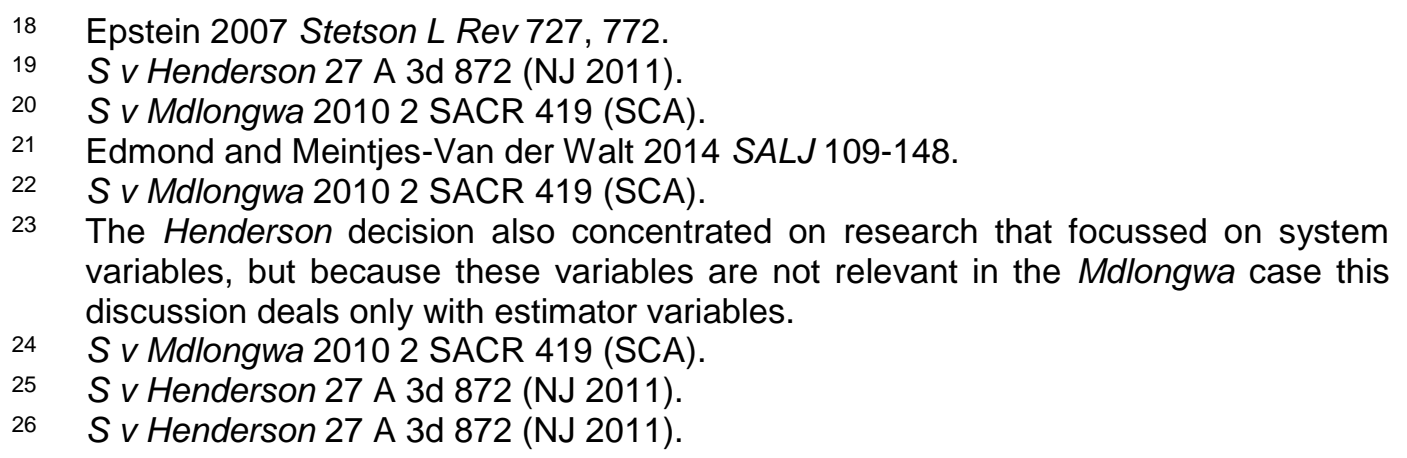
variables, but because these variables are not relevant in the Mdlongwa case this discussion deals only with estimator variables.

24 S v Mdlongwa 20102 SACR 419 (SCA).

$25 S$ v Henderson 27 A 3d 872 (NJ 2011).

$26 \quad S$ v Henderson 27 A 3d 872 (NJ 2011). 
Manson $^{27} /$ Madison $^{28}$ test in evaluating eyewitness identification evidence. The New Jersey Supreme Court undertook a thorough and comprehensive survey of the current scientific and legal state of eyewitness identification. This survey grew out of a court-ordered hearing on eyewitness identification conducted by a court-appointed Special Master, retired judge Gaulkin, ${ }^{29}$ who heard testimony by seven experts that ultimately "produced more than 2,000 pages of transcripts along with hundreds of scientific studies". 30 These studies presented at the hearing, and ultimately relied upon by the court, are based on serious and verifiable science. ${ }^{31}$ The Special Master found that out of 64 cognitive psychologists, social psychologists and other experts surveyed, ${ }^{32}$ "[n]inety percent or more" found research on

27 Manson v Brathwaite 432 US 98 (1977). In terms of Manson, a defendant must show that suggestive police procedures were used during an eyewitness identification to obtain a pretrial hearing on the admissibility of the evidence. If the court determines the procedures are not "impermissibly suggestive", then the trial judge will admit the eyewitness evidence without considering any other variables that might bear on the reliability of the identification. Where the identification is questionable, the remedy under Manson is to suppress the evidence as a whole. This, however, is seldom done in practice.

$28 S$ v Madison $109 \mathrm{NJ}$ 223, 536 A 2d 254 (1988). The second prong of the so-called Manson/Madison test requires consideration of five factors: (1) the opportunity of the witness to view the suspect at the time of the crime; (2) the witness's degree of attention; (3) the accuracy of the witness's prior description of the suspect; (4) the level of certainty demonstrated at the confrontation; and (5) the time between the crime and the confrontation.

29 A "special master" is "a representative of the court appointed to hear a case involving difficult or specialized issues". (FARLEX 2014 http://bit.ly/1XfviB3)

30 Supreme Court of New Jersey $2008 \mathrm{http} / / /$ bit.ly/1VP6ikK (hereafter "Report of the Special Master).

$31 \quad S$ v Henderson 27 A 3d 872 (NJ 2011). "The research [relied upon by the court] represents the gold standard in terms of the applicability of social science research to law. Experimental methods and findings have been tested and retested, subjected to scientific scrutiny through peer-reviewed journals, evaluated through the lens of metaanalyses, and replicated at times in real-world settings." (internal quotation marks omitted).

32 Report of the Special Master 26: "Ninety-two percent of the participating experts had published articles or books on eyewitness identification, and many in the group had testified as expert witnesses in almost 1,000 court cases, collectively." (citation omitted). 
eyewitness identification reliable. ${ }^{33}$

Based on the fact that judicial precedent and research findings are at variance, the court held that "[v]irtually all of the scientific evidence"34 that had emerged in recent decades "reveals that an array of variables can affect and dilute memory and lead to misidentifications". 35

\subsection{The facts}

Henderson was prosecuted for homicide and was inter alia convicted of reckless manslaughter. He claimed that he had been misidentified by an eyewitness, W, who was present in the apartment of the deceased when two armed men forcibly entered. One of the men, who was a stranger to $W$, held $W$ at gunpoint while the other, who was known to $W$, shot the deceased. Two weeks later, $W$ attended a photo display line-up conducted by a detective who was not engaged in the investigation. However, when W was unable to make an identification two of the case detectives intervened. This was in breach of the Attorney-General's Guidelines for Preparing and Conducting Photo and Live Line-up Identification Procedures.

According to the approach used in the Henderson case, a trial court may, at a pretrial hearing, apply its mind to factors which could have impacted on the reliability of an eyewitness' identification, provided that a defendant can present evidence of a system variable which might have allowed prompting or suggestion at an eyewitness identification event. The eyewitness evidence will be suppressed by the trial judge if the defendant can prove "a very substantial likelihood of irreparable misidentification". ${ }^{36}$

The increase in attention devoted to the science of eyewitness identification has resulted in a better understanding of how human memory works. Understanding how memory works has, in turn, given rise to substantial concerns regarding the ability of eyewitnesses to make accurate identifications from memory. ${ }^{37}$ Memory

33 Report of the Special Master 26: "Ninety percent or more of the experts found research on the following topics reliable: suggestive wording; lineup instruction bias; confidence malleability; mugshot bias; post-event information; child suggestivity; alcohol intoxication; and own-race bias. Seventy to $87 \%$ found the following research reliable: weapon focus; the accuracy confidence relationship; memory decay; exposure times; sequential presentation; show-ups; description-matched foils; child-witness accuracy; and lineup fairness." (citations omitted).

$34 \quad S$ v Henderson 27 A 3d 872 (NJ 2011); Report of the Special Master 12.

$35 S$ V Henderson 27 A 3d 872 (NJ 2011); Report of the Special Master 3.

36 Manson v Brathwaite 432 US 98 (1977); S v Henderson 27 A 3d 872 NJ (2011).

37 Report of the Special Master 14-15. 
consists of three stages: acquisition - "the perception of the original event"; retention - "the period of time that passes between the event and the eventual recollection of a particular piece of information"; and retrieval - the "stage during which a person recalls stored information". ${ }^{38}$

At each of those stages the "information ultimately offered as 'memory' can be distorted, contaminated and even falsely imagined". ${ }^{39}$ The court did not attempt to list all of the factors that can result in distortion, contamination, or false memory, but indicated that scientists have isolated many of the factors that can result in a misidentification by an eyewitness. ${ }^{40}$ As stated above, some of those factors, called "system variables" 41 "are within the control of the criminal justice system", while "estimator variables"42 cannot be addressed by reforming the system.

The court considered the research and Special Master's findings on estimator variables and held that the following estimator variables should be taken into consideration in determining the reliability of eyewitness evidence.

\subsection{Estimator variables that have an effect on the reliability of eyewitness evidence}

\subsubsection{Stress}

High stress levels drastically reduce the accuracy of eyewitness memory. ${ }^{43}$ The court found that individuals tend to recall information best under conditions of moderate stress or arousal. ${ }^{44}$ Based on the report of the Special Master, the court confirmed the negative correlation between stress and the accuracy of eyewitness recall. That is, the more stress undergone by a witness at the time of an event, the lower her ability to recall the details of that event - including the identity of the perpetrator.

38 Report of the Special Master 14.

39 Report of the Special Master 14.

40 Report of the Special Master 8-26.

41 System variables include the following: blind administration, pre-identification instructions, lineup construction, avoiding feedback and recording confidence, multiple viewings, simultaneous versus sequential lineups, composites, and show ups. Report of the Special Master 15-20.

42 Estimator variables include the following: stress, weapon focus, duration, distance and lighting, witness characteristics, characteristics of the perpetrator, memory decay, race bias, private actors, and speed of identification. Report of the Special Master 2025.

$43 \quad S v$ Henderson 27 A 3d 872 (NJ 2011).

$44 \quad S v$ Henderson 27 A 3d 872 (NJ 2011). 
The example used to illustrate this correlation is based on the 2004 study by Charles Morgan. ${ }^{45}$ The researchers used a military "survival training" scenario to test the correlation between stress and the accuracy of recall. The test subjects were active-duty military personnel with an average age of 25 and an average length of service of 4 years.

Each person was subjected to both stressful and non-stressful interrogation and afterwards various methods were used to test the subjects' ability to identify the person who had performed the interrogation. The stressful scenario involved interrogation for a period of forty minutes in a brightly lit room while the interrogator faced the subject. A mere 34 per cent of the subjects could correctly identify the interrogator. In a similar scenario which involved low stress, 76 per cent of the subjects could identify the interrogator from a photo lineup. In a different sample, 68 per cent of the subjects exposed to high stress selected a person other than the real interrogator from the photographs provided, while only 12 per cent of the subjects involved in the low stress experiment chose the wrong person. ${ }^{46}$

The experiment outlined above, which was referred to by the court, clearly indicates how stress can affect eyewitness recall. The findings of this experiment strongly indicate that courts which consider gun shots and homicidal threats as "events that tend to focus a witnesses' [sic] attention"47 could misdirect themselves as the scientific evidence suggests that these kinds of stressful events could make recall difficult.

The factors outlined above could result in misidentifications. Every misidentification could potentially result in the decision- maker finding an innocent person guilty.

The Henderson court found that high levels of stress are likely to affect the reliability of a witness' identification but that there is no precise measure of "high stress" and it must be assessed in individual cases. ${ }^{48}$ The prosecution agreed that high levels of stress are more likely than low levels to impair identification. Scientific research affirms that conclusion. A meta-analysis of 63 studies showed "considerable support for the hypothesis that high levels

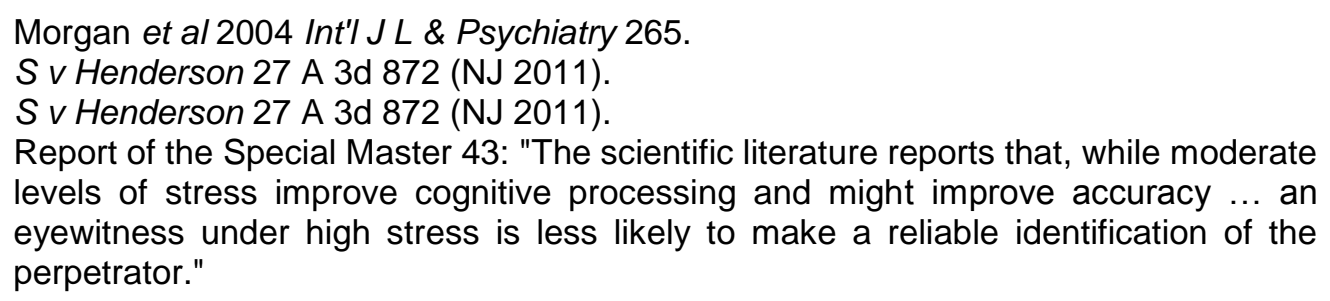
levels of stress improve cognitive processing and might improve accuracy ... an eyewitness under high stress is less likely to make a reliable identification of the perpetrator." 
of stress negatively impact both accuracy of eyewitness identification as well as accuracy of recall of crime-related details". ${ }^{49}$

\subsubsection{Weapon focus}

Weapon focus refers to a factor that affects the reliability of eyewitness testimony. ${ }^{50}$ Where a weapon is used during a crime, the weapon is likely to divert the witness's attention to the weapon that the perpetrator is holding and this affects the ability of the witness to concentrate on the details of the crime. ${ }^{51}$ The visual attention given by a witness to a weapon can impair his or her ability to make a reliable identification and describe what the culprit looks like if the crime is of short duration. ${ }^{52}$

The focused attention that an eyewitness pays to the weapon that the perpetrator holds during the commission of the alleged crime forms the basis of this concept. The proponents of this view believe that all the visual attention of the eyewitness gets drawn to the weapon, thereby affecting the ability of the eyewitness to observe other details. Chief Justice Rabner acknowledged the results of a meta-analysis undertaken by Nancy Steblay $^{53}$ on this topic. In this meta-analysis, data from various studies on this subject was collected and analyzed to determine if the presence of a weapon may actually be a factor affecting the memory or perception of an eyewitness to a real crime. Of the 19 weapon-focus studies that involved more than 2,000 identifications, Steblay found an average decrease in accuracy of about 10 per cent when a weapon was present. In a separate study, half of the witnesses observed a person holding a syringe in a way that was personally threatening to the witness; the other half saw the same person holding a pen. ${ }^{54}$ Sixty-four per cent of the witnesses from the first group misidentified a filler from a target-absent lineup, compared to thirtythree from the second group. ${ }^{55}$ Weapon focus can also affect a witness's ability to describe a perpetrator. A meta-analysis of ten studies showed that

$49 \quad S v$ Henderson 27 A 3d 872 (NJ 2011). The court referred to Deffenbacher et al 2004 Law \& Hum Behav 687-708. This approach was also followed in $S v$ Lawson 352 Or 724 (2012) 771-772 and S v Guilbert 306 Conn 218 (2012) 253.

$50 \quad S v$ Henderson 27 A 3d 872 (NJ 2011).

$51 \quad S v$ Henderson 27 A 3d 872 (NJ 2011).

$52 S$ v Henderson 27 A 3d 872 (NJ 2011).

$53 \quad S v$ Henderson 27 A 3d 872 (NJ 2011). Rabner J refers to Steblay 1992 Law \& Hum Behav 413, 415-417

$54 \quad S v$ Henderson 27 A 3d 872 (NJ 2011). The court referred to Maass \& Köhnken 1989 Law \& Hum Behav 397, 401-402.

55 S v Henderson 27 A 3d 872 (NJ 2011). The court also referred to Pickel "Remembering and Identifying Menacing Perpetrators" 339, 353-354 (noting that "unusual items [like weapons]" attract attention). 
"weapon-absent condition[s] generated significantly more accurate descriptions of the perpetrator than did the weapon-present condition". ${ }^{56}$ Thus, especially when the interaction is brief, the presence of a visible weapon can affect the reliability of an identification and the accuracy of a witness's description of the perpetrator.

\subsubsection{Duration}

The length of time an eyewitness observes an event may affect reliability. ${ }^{57}$ The Henderson court accepted the finding of the Special Master that "while there is no minimum time required to make an accurate identification, a brief or fleeting contact is less likely to produce an accurate identification than a more prolonged exposure". ${ }^{5}$

Judge Rabner held:

There is no measure to determine exactly how long a view is needed to be able to make a reliable identification. Dr Malpass testified that very brief but good views can produce accurate identifications, and Dr Wells suggested that the quality of a witness' memory may have as much to do with the absence of other distractions as with duration. Whatever the threshold, studies have shown, and the Special Master found, 'that witnesses consistently tend to overestimate short durations, particularly where much was going on or the event was particularly stressful. ${ }^{59}$

\subsubsection{Distance and lighting}

Greater distance and poor lighting can lessen reliability. ${ }^{60} \mathrm{It}$ is obvious that it is easier to recognise a person when that person is close by, and that clarity decreases with distance. ${ }^{61}$ Poor lighting makes it harder to see well. ${ }^{62}$ Therefore a greater distance between a witness and a perpetrator and poor lighting conditions can reduce the reliability of an identification. ${ }^{63}$ Further research by scientists has provided additional evidence of these commonsense notions. ${ }^{64}$

56 S v Henderson 27 A 3d 872 (NJ 2011). The court referred to Steblay 1992 Law \& Hum Behav 417.

$57 \quad S v$ Henderson 27 A 3d 872 (NJ 2011).

$58 \quad S v$ Henderson 27 A 3d 872 (NJ 2011). The court referred to research by Tredoux "Eyewitness Identification" 875, 877.

$59 \quad S v$ Henderson 27 A 3d 872 (NJ 2011). The view of the Special Master that was accepted by the court is based on Loftus et al 1987 Appl Cogn Psychol 10.

$60 \quad S v$ Henderson 27 A 3d 872 (NJ 2011).

$61 \quad S v$ Henderson 27 A 3d 872 (NJ 2011).

$62 S v$ Henderson 27 A 3d 872 (NJ 2011).

$63 \quad S v$ Henderson 27 A 3d 872 (NJ 2011).

$64 S v$ Henderson 27 A 3d 872 (NJ 2011). The court referred to research by Lindsay et al 2008 Law \& Hum Behav 526. 


\subsubsection{Witness characteristics}

Judge Rabner recognised that characteristics like age and the level of intoxication can affect the reliability of eyewitness testimony. The court referred to the findings of the Special Master based on the work of Dysart et $a l,{ }^{65}$ which indicates that "the effects of alcohol on identification accuracy show that high levels of alcohol promote false identifications" and that "low alcohol intake produces fewer misidentifications than high alcohol intake". 66 The court also based its judgment on work done by Pozzulo and Lindsay, ${ }^{67}$ according to which factors such as a witness's age and level of intoxication can affect the reliability of an identification. Other research also shows that witness accuracy declines with age. This was shown across twelve studies. Young witnesses - ranging from nineteen to twenty-four years old - were more accurate when viewing target-absent lineups than older witnesses ranging from sixty-eight to seventy-four years old. ${ }^{68}$ Research is, however, inconclusive on specific age as a factor in the reliability of identifications. ${ }^{69}$

\subsubsection{Characteristics of the perpetrator}

Disguises and changes in facial features can affect a witness's ability to remember and identify a perpetrator. The Special Master found that "[d]isguises (e.g hats, sunglasses, masks) are confounding to witnesses and reduce the accuracy of identifications". ${ }^{70}$ According to the State, those findings are "so well-known that criminals employ them in their work". ${ }^{71}$ Disguises as simple as hats have been shown to reduce identification accuracy. ${ }^{72}$ If facial features are altered between the time of the event and the identification procedure - if, for example, the culprit grows a beard - the accuracy of an identification may decrease. ${ }^{73}$

$65 S v$ Henderson 27 A 3d 872 (NJ 2011). The court referred to Dysart et al $2002 \mathrm{~J}$ Appl Psychol 170.

$66 \quad S v$ Henderson 27 A 3d 872 (NJ 2011).

$67 \quad S v$ Henderson 27 A 3d 872 (NJ 2011). Pozzulo and Lindsay 1996 Law \& Hum Behav 549.

68 Pozzulo and Lindsay 1996 Law \& Hum Behav 549. S v Henderson 27 A 3d 872 (NJ 2011).

$69 \quad S v$ Henderson 27 A 3d 872 (NJ 2011).

$70 S$ v Henderson 27 A 3d 872 (NJ 2011).

$71 S$ v Henderson 27 A 3d 872 (NJ 2011).

$72 S$ v Henderson 27 A 3d 872 (NJ 2011). Reference is made to Cutler et al $1987 \mathrm{~J} \mathrm{Appl}$ Psychol 629, 635.

73 S v Henderson $27 \mathrm{~A} 3 \mathrm{~d} 872$ (NJ 2011). The court referred to Patterson and Baddeley 1977 J Exp Psychol Hum Learn Mem 406, 410, 414. 


\subsubsection{Memory decay}

The length of time between an incident and an identification, referred to as the "retention interval", affects the accuracy of eyewitness identifications. ${ }^{74}$ Memories fade with time; thus there is a greater possibility that a witness' memory of the perpetrator will weaken as time passes. The court accepted the Special Master's observation that memory decay "is irreversible" memories never improve. ${ }^{75}$ As a result, delays between the commission of a crime and the time an identification is made can affect reliability. This basic principle was held not to be in dispute.

A meta-analysis by Deffenbacher ${ }^{76}$ of fifty-three "facial memory studies" confirmed "that memory strength will be weaker at longer retention intervals than at briefer ones". The court concluded that the more time that passes, the greater the possibility that a witness' memory of a perpetrator will weaken. ${ }^{77}$

\subsubsection{Race-bias}

The court previously recognised that a witness may have more difficulty making a cross-racial identification and it continues to be a factor that can affect reliability. ${ }^{78}$

\subsection{Commentary}

The foregoing factors produce varying but significant rates of misidentifications. Each time a misidentification occurs, there is a strong possibility that a jury will find an innocent person guilty. The Supreme Court of New Jersey elaborated and held that:

study after study revealed a troubling lack of reliability in eyewitness identifications. From social science research to the review of actual police lineups, from laboratory experiments to DNA exonerations, the record proves that the possibility of mistaken identification is real. Indeed, it is now widely known that eyewitness misidentification is the leading cause of wrongful convictions across the country. ${ }^{79}$

Realising that the legal framework at that time failed to adequately protect defendants against misidentifications, the New Jersey court changed its

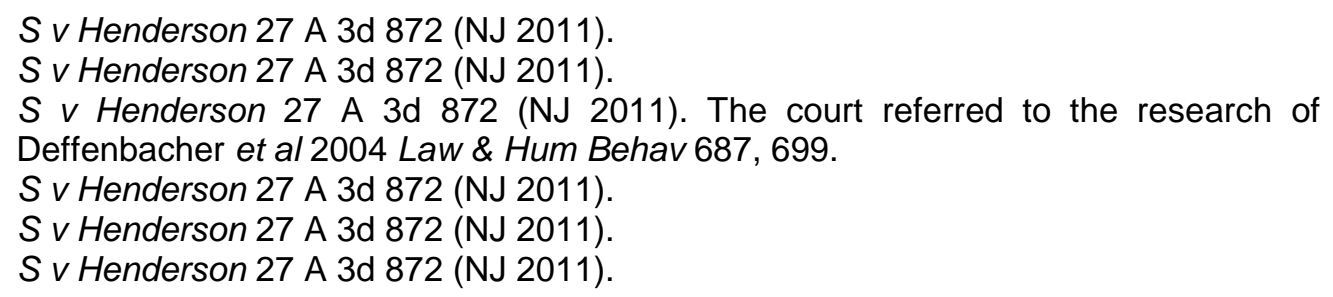


treatment of eyewitness identification. The court now allows pretrial hearings for accused persons who can show some evidence that suggestion occurred during the identification. ${ }^{80}$ At the pretrial hearing, the court will investigate all relevant factors that might "affect reliability in deciding whether an identification is admissible". ${ }^{81}$ On request of the court the New Jersey's Criminal Practice Committee drafted revised jury instructions relating to eyewitness identification and the factors that can lead to misidentifications. ${ }^{82}$ These instructions ${ }^{83}$ are considered in the conclusion below.

Although the Henderson decision currently affects only the standard for the admissibility of eyewitness identification in New Jersey, the insight of the court in acknowledging eyewitness science represents a great step forward in the recognition of how scientific research can inform legal decisionmaking. The section that follows below evaluates the South African Supreme Court of Appeal's approach ${ }^{84}$ to eyewitness evidence as compared to $S v$ Henderson.

\section{$3 \quad S$ v Mdlongwa 20102 SACR 419 (SCA)}

\subsection{Introduction}

In $S$ v Ngcobo ${ }^{85}$ Didcott $\mathrm{J}$ took judicial notice of Eyewitness Testimony by Elizabeth Loftus ${ }^{86}$ in stating that:

[t] he danger of mistaken identification is one to which all judicial officers are or should certainly be alive. Enough has been said about it over the years, and in various parts of the world to see to that. ${ }^{87}$

This approach by Didcott $\mathrm{J}$ was criticised in that this was not a fact that judicial notice could be taken of ${ }^{88}$ Unlike some expert evidence such as Battered Woman's Syndrome ${ }^{89}$ South African courts have not been willing to hear expert evidence on the limitations of eyewitness testimony as it is considered to be within the common knowledge of judicial decision makers.

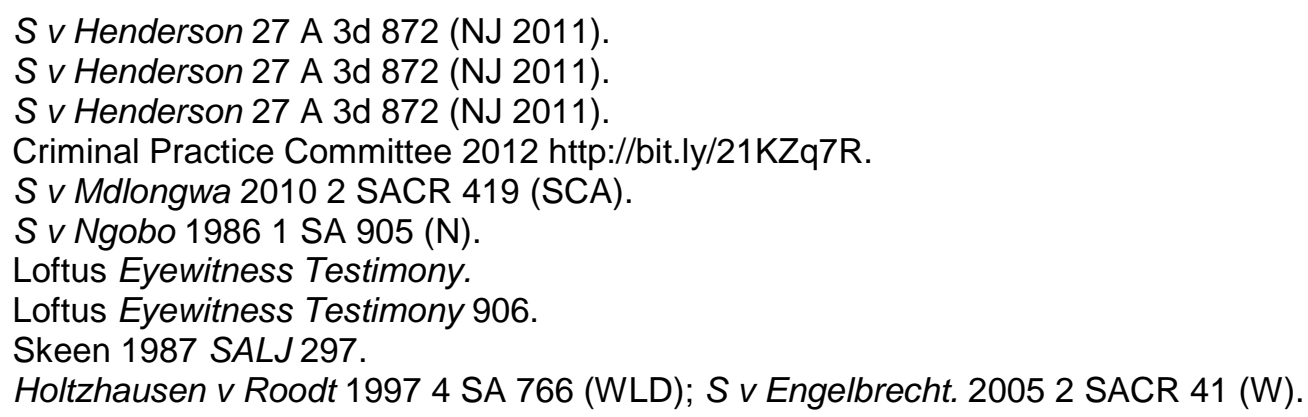




\subsection{The facts}

On 11 February 2004 five men entered the NBS Building Society in Dundee, KwaZulu-Natal, and robbed the bank of R50 000. This event is reflected in a number of still images taken from nine CCTV cameras placed in the bank. The images taken from the video inter alia showed a person standing next to the security guard and another person wearing a blue Adidas T-shirt and blue Adidas shorts who entered the glass offices of the bank. On 26 September 2005, five men were prosecuted in the Regional Court, Dundee, for armed robbery. The appellant, who was accused four, as well as accused five, were found guilty on this charge and sentenced to 20 years' imprisonment.

The State's case was based on a dock identification of accused four and accused five and facial comparison evidence by a police expert, $\mathrm{N}$. For the purposes of comparison, the witness used a still image from the CCTV footage, Exhibit 29, and compared that with a photograph marked as Exhibit $\mathrm{K}$. She asserted that Exhibit $\mathrm{K}^{90}$ and Exhibit 29 depicted the same person and that that person was the appellant (accused four). She was unable to identify accused four in court. The appellant pleaded not guilty, denied that he participated in the robbery and stated that he was elsewhere on the day in question, but also that he was not the person depicted in the photograph, Exhibit $\mathrm{K}$. The person identified by $\mathrm{N}$ as accused four in the still image taken from the CCTV footage was a person wearing a blue Adidas T-shirt and blue shorts from the same brand (Exhibit 29). The security guard, Mbatha, however, testified that it was accused five wearing the Adidas outfit. No identification parade was held. The appellant was legally represented and elected not to testify.

\subsection{The Appeal and SCA judgment}

The appellant appealed against the judgment of the magistrate to the High Court of Kwazulu-Natal and judgment was given on 26 February 2009. ${ }^{91}$ Swain $\mathrm{J}$ (Radebe $\mathrm{J}$ concurring) dismissed this appeal, finding Mbatha an "excellent witness" and his identification reliable on the basis that the appellant "was always next to me carrying the firearm". ${ }^{92}$ The court also referred to the evidence of $\mathrm{N}$ and noted that photograph F30 taken from the video footage in the "Standard Bank" (sic) ${ }^{93}$ and Exhibit $L$ portrayed the

\footnotetext{
90 Showing a person wearing blue Adidas clothing.

91 Trial transcript 571-574. Record of appeal Vol 7.

92 Trial transcript 572 . Record of appeal Vol 7.

93 The robbery took place at the NBS Building Society.
} 
appellant. ${ }^{94}$ Consequently the appeal was dismissed. The appellant then made a further application for leave to appeal before Judge Swain. The appellant argued his own application as he had exhausted his right to legal aid representation. ${ }^{95}$ Swain $\mathrm{J}$ engaged the appellant and showed him photograph F30 stating that "I can even see that that is you in the photo". ${ }^{96}$ After a lengthy exchange between the judge and the appellant the prosecutor interceded indicating that the comparison photograph should be Exhibit $\mathrm{K}$ and not $\mathrm{L}$ and that Exhibit $\mathrm{K}$ should have been compared with the video footage still, Exhibit 29.97 The appellant maintained that neither photograph $\mathrm{K}$ nor $\mathrm{L}$ was a photograph of him. As a result of the confusion, Swain J (Gorven J) granted leave to appeal to the Supreme Court of Appeal.

In the Supreme Court of Appeal, the appellant, Mdlongwa, challenged his conviction on the following grounds: a) that the testimony of the security officer, Mbatha, who had been positioned outside the bank was "unsatisfactory and contradictory" 98 and that no weight should be attached to his dock identification of the appellant; ${ }^{99} \mathrm{~b}$ ) that Inspector N, the facial comparison expert called by the prosecution, was no "expert" as she lacked academic qualifications and that her conclusions were not acceptable as "it was not of a generally accepted standard" 100 and c) that the video footage of the robbery was not admissible as it was not the original. ${ }^{101}$

At the outset of the judgment Salduker AJA, writing for the unanimous court, explicitly states that the "sole issues for the determination on appeal is whether the appellant was properly identified as one of the robbers". ${ }^{102}$

94 Trial transcript 573. Record of appeal Vol 7. The judge went further and stated that "[i]n my view these two photos that form the subject matter of Inspector N's analysis, there is a striking similarity between these two individuals. The similarity is so striking that I am satisfied that the same individual is depicted" (573). During address from the legal representative of the appellant, the judge invites counsel to look at the photographs and to give an opinion on whether the person depicted in the photographs and the appellant is not one and the same person. This is conceded by counsel (569).

95 Trial transcript 584-600. Record of appeal Vol 7.

$96 \quad$ Trial transcript 586. Record of Appeal Vol 7.

97 Trial transcript 593-595. Record of Appeal Vol 7.

98 S v Mdlongwa 20102 SACR 419 (SCA).

$99 \quad S v$ Mdlongwa 20102 SACR 419 (SCA).

$100 S v$ Mdlongwa 20102 SACR 419 (SCA). The inherent unreliability of the facial comparison evidence is discussed in another article: Edmond and Meintjes-Van der Walt 2014 SALJ.

101 S v Mdlongwa 20102 SACR 419 (SCA).

$102 S$ v Mdlongwa 20102 SACR 419 (SCA) para 5. 
The court acknowledged that the only direct evidence of identification of the appellant was a dock identification by the security guard, Mbatha. ${ }^{103} \mathrm{He}$ testified that accused five was wearing a blue T-shirt, yet according to the video stills, it is the person identified by the facial comparison expert as the appellant ${ }^{104}$ (my emphasis) who was wearing the blue T-shirt. ${ }^{105}$ It was also found that Mbatha's identification of the appellant was "corroborated" by the facial mapping identification of the appellant by the expert witness.

In the light of the above, there are certain issues in the judgment that need closer examination.

\subsection{Eyewitness identification}

The SCA quite correctly indicated that the only direct evidence of identification of the appellant was the dock identification by the security guard, Mbatha, ${ }^{106}$ on 26 September 2006, 19 months after the incident. The first ground of appeal was that Mbatha's evidence was unsatisfactory and contradictory, and that no reliance could be placed on his dock identification.

Mbatha's evidence of identification of the appellant was in respect of what he observed during the robbery at the bank and his subsequent dock identification. No identification parade was held. The court found that "[a]ccording to Mbatha's testimony, accused five wore a blue T-shirt, and that the appellant stood next to him [Mbatha] carrying a firearm". ${ }^{107}$

Mbatha's evidence was that on 11 February 2004 he was on duty outside the bank ${ }^{108}$. He testified that two people approached him. ${ }^{109} \mathrm{He}$ described one as having a short haircut and the other as wearing blue Adidas shorts and an Adidas T-shirt. ${ }^{110}$ During his entire testimony this was the only description that Mbatha could give of these two persons whom he identified as accused four (the appellant) and accused five. He mentioned no facial characteristics or other identifying marks. He maintained that the reason for him being able to identify accused four and five was the fact that they spoke to him.

\footnotetext{
103 S v Mdlongwa 20102 SACR 419.

$104 S$ v Mdlongwa 20102 SACR 419 (SCA).

$105 S$ v Mdlongwa 20102 SACR 419 (SCA) para 9.

$106 S$ v Mdlongwa 20102 SACR 419 (SCA) para 24.

$107 S$ v Mdlongwa 20102 SACR 419 (SCA) para 9.

$108 S$ v Mdlongwa 20102 SACR 419 (SCA) para 6.

$109 S$ v Mdlongwa 20102 SACR 419 (SCA).

$110 S$ v Mdlongwa 20102 SACR 419 (SCA).
} 
He testified that while they were speaking to him a third person was standing at a lotto machine which was on the opposite side to where the bank is situated. ${ }^{111}$ One of two men who initially approached him drew a firearm and ordered the witness (the security guard) to allow them as well as the person who stood at the lotto machine and two others to enter. ${ }^{112} \mathrm{His}$ evidence was that during the entire incident the person who had the firearm and who entered with him and remained with him was accused four, the appellant. He then relates the mayhem that occurred during the robbery: He noticed that there were two who entered the kitchen area and then proceeded to the enquiries section, where one of them hit Mr Mabaso, the enquiries clerk, with a crowbar and demanded that he open the door. ${ }^{113} \mathrm{He}$ testified that the person who assaulted Mr Mabaso wore short pants and a blue T-shirt. According to his testimony the robbery took approximately ten minutes. ${ }^{114}$ Yet according to the actual time as reflected by the CCTV cameras, the robbery took two minutes and ten seconds. ${ }^{115}$ The person who was with him and who was armed with the firearm pointed the firearm at Ayesha Ishmael, one of the tellers who was behind the glass on the other side and shouted "open, open, open". ${ }^{116}$ Ayesha then opened the door leading to the tellers' section, which was entered. ${ }^{117}$ According to him, they opened the shelves and one went to the manager's office, but what transpired there he could not see. ${ }^{118}$ Mbatha conceded that he was scared, and "shocked".

According to him he saw two firearms, one held by the person who was with him and the other one by the person who pointed the firearm at $\mathrm{Mr}$ Mabaso. ${ }^{119} \mathrm{He}$ said that the person who was with him had hair that was cut short and that the one who had the crowbar and who hit Mr Mabaso was one of the two people who entered first. The latter wore short pants and a blue T-shirt and was the one who hit Mr Mabaso with the crowbar. ${ }^{120}$

\footnotetext{
$111 S$ v Mdlongwa 20102 SACR 419 (SCA) para 6.

$112 S$ v Mdlongwa 20102 SACR 419 (SCA) para 7.

113 S v Mdlongwa 20102 SACR 419 (SCA) para 7. Trial transcript 72. Record of Appeal Vol 1.

$114 S$ v Mdlongwa 20102 SACR 419 (SCA). Trial transcript 91. Record of Appeal Vol 1.

$115 S$ v Mdlongwa 20102 SACR 419 (SCA). Trial transcript 216-217. Record of Appeal Vol 1. See the evidence by Viljoen at 422-423.

116 Trial transcript 74. Record of Appeal Vol 1.

117 Trial transcript 75-76. Record of Appeal Vol 1.

118 Trial transcript 92 and 96. Record of Appeal Vol 1.

119 Trial transcript 216-217. Record of Appeal Vol 1.

120 Trial transcript 217. Record of Appeal Vol 1.
} 


\subsection{Commentary}

The court had to consider not only whether, considering all the evidence, it could be said that the State had proven each and every element of the offence charged beyond reasonable doubt, but also whether the State had proven beyond reasonable doubt that it was the appellant who committed the robbery.

\subsubsection{Caution and corroboration}

In South Africa a cautionary rule to guard against eyewitness mistakes was recognised as early as $S v$ Mokoena: ${ }^{121}$

[T] he uncorroborated evidence of a single competent and credible witness is no doubt declared to be sufficient for a conviction... but in my opinion that [witness] should only be relied on where the evidence of the single witness is clear and satisfactory in every material respect. ${ }^{122}$

In $R v$ Mputing ${ }^{123}$ Boshoff $\mathrm{J}$ mentioned the following factors that can affect the observation of the accused person(s): i) the ability of the witness to observe ii) the impression that the observation had on the observer; iii) the time lapse after such observation; iv) the ability of the observer to distinguish between what he/she actually remembers and what he or she infers from the observation made.

Despite the general consensus about the fragility of eyewitness evidence, as recognised in South African law, ${ }^{124}$ neither the Regional Court judgment, the High Court judgment nor the Appeal Court judgment mentioned that such evidence should be approached with caution. The Supreme Court of Appeal did, however, indicate that some of the evidence was "corroborated". ${ }^{125}$ These apparent corroborations are discussed below.

Mbatha's testimony was that accused four (the appellant) was not wearing the blue Adidas shorts and T-shirt. The court concedes that there is a stark contradiction between the evidence of Mbatha and the evidence of the facial comparison expert's identification, which asserted that it was the appellant who was wearing the blue Adidas clothing. ${ }^{126}$ The court then argues that

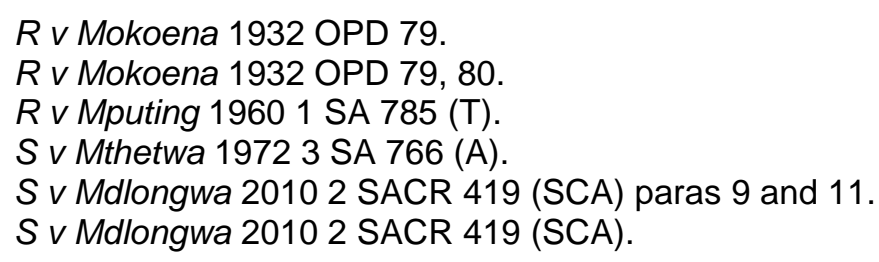


[i]f one examines Mbatha's evidence, except for the description of the clothing worn by two of the robbers, whom he identified as the appellant and accused five, his testimony is completely in line with what is portrayed on the video footage and the stills as having taken place during the robbery. ${ }^{127}$

As it cannot be said that the appellant was wearing the blue Adidas clothing, it is difficult to follow the court's argument. Mbatha's identification rests solely on the clothing that accused five was wearing and the hairstyle of the appellant. However, as the court conceded, this is in complete contradiction to the video stills. From this it should follow that the dock identification by Mbatha and the expert identification of Inspector $\mathrm{N}$ are diametrically different. The difference is so great and contradictory that this should have been the end of the matter and the appellant should have been acquitted. In my view there was no way in which this contradiction, which goes to the heart of the matter, could be rationalised. However, Salduker AJA then asserts that Mbatha's contradictory evidence "should not be seen in isolation", ${ }^{128}$ as Mbatha's evidence that one of the robbers wore a blue Tshirt was corroborated by Ms Botes, a branch manager at the NBS bank. She testified that she was seated in her office when she was confronted by one of the robbers wearing a blue T-shirt with an inscription in white with a capital letter "A", and that he ordered her to open the safe. ${ }^{129}$ This so-called corroboration as conceded by the court merely corroborates that one of the robbers was wearing those clothes and therefore it does not corroborate the identification of the appellant (my emphasis).

The following sentence in the judgment also requires comment:

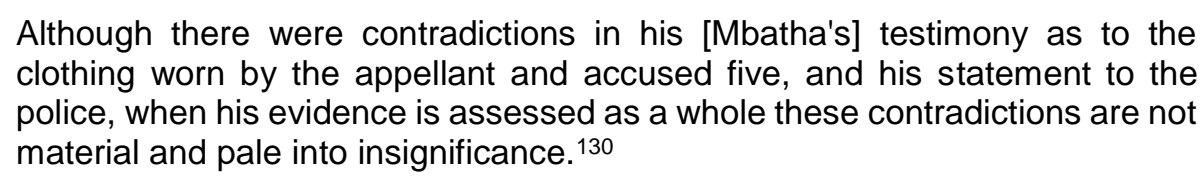

The contradictions are serious. They cannot be ignored, yet the court does not believe that these contradictions are material and significant. The court does not give any reasons why little value should be attached to the contradictions except to state that when his evidence is "assessed as a whole", these contradictions are not significant. However, there is no other evidence emanating from him that could justify this view of the court. The only evidence given by him on the factum probandum (the identification of

127 S v Mdlongwa 20102 SACR 419 (SCA) para 9.

$128 S$ v Mdlongwa 20102 SACR 419 (SCA) para 9.

$129 S$ v Mdlongwa 20102 SACR 419 (SCA) para 9.

$130 S$ v Mdlongwa 20102 SACR 419 (SCA) para 11. 
the appellant) is that which is contradictory to the other evidence proffered by the State.

Mbatha's evidence identifying the appellant as the person next to him is supported by the CCTV footage as the stills show a person standing next to him with a light blue shirt with rolled up sleeves. ${ }^{131}$ The video images also show another person dressed in Adidas clothing, who is seen entering the bank offices. This is the person he identifies as accused five. It cannot therefore be said that the video stills also corroborate the identification of the appellant by Inspector $\mathrm{N}$, as the person she identified is the person who was wearing the Adidas clothes.

\subsubsection{Memory decay}

As pointed out in Henderson above, memories fade with time. The longer the intervening period of time, the greater the risk of error. The fact that 19 months had passed between the robbery and the evidence given by Mbatha, does not appear to have been factored into the evaluation of his evidence.

\subsubsection{Stress and weapon focus}

It is conceded in Mdlongwa that the circumstances in which the eyewitness, Mbatha, found himself were extremely stressful, which stress could have impacted on his ability to encode what was happening, and therefore it could well have been harder for him to identify the appellant.

During the robbery Mbatha was confronted not with only one firearm, but according to the Court, with two firearms as well as with a crowbar that was used to attack the teller, Mabaso. The presence of a visible weapon may reduce the reliability of the identification, especially if the crime is of short duration. Another statement of the court requires comment: "He may have been innocently mistaken about the apparel of the robbers, which is understandable in the circumstances, given that a gun was pointed at him." 132 Here the court seems to make an excuse for the fact that there is a contradiction by stating that fear might have caused the mistaken identification. The research mentioned in Henderson shows that high levels of stress and fear are likely to affect the reliability of a witness' identification. It has also been shown that high levels of stress can diminish an eyewitness' ability to recall and make an accurate identification. How the court could

\footnotetext{
131 S v Mdlongwa 20102 SACR 419 (SCA) para 9.

$132 S$ v Mdlongwa 20102 SACR 419 (SCA) para 11.
} 
conclude that stress and fear which are known negatively to affect the reliability of eyewitness testimony could assist the State's case in respect of the identification of the appellant is difficult to comprehend. The court conceded that Mbatha may have been innocently mistaken about the apparel of the robbers, which it held was understandable in the circumstances, given that a gun was pointed at him.

This is the very problem that leads to mistaken identity. Even if a witness is truthful, factors identified in Henderson and other South African case law make identification evidence dangerous. In $S v$ Ndika $^{133}$ Marais JA also observed: "It is of course so that the honesty of a witness in identifying a person is not by itself a guarantee of its correctness." 134

Case law in South Africa and other jurisdictions following the AngloAmerican tradition has indicated that the real danger with identification evidence is that witnesses can make bona fide mistakes. The court's reasoning that the identification must be correct because Mbatha had no reason to falsely implicate the appellant and accused ${ }^{135}$ is highly problematic.

\subsubsection{Duration}

Despite the fact that Mbatha testified that the robbery lasted close to ten minutes, the recording by the CCTV cameras indicated that the entire episode lasted only 2 minutes and 10 seconds. ${ }^{136}$ The Henderson court held that identifications based on such a short period and in such chaotic circumstances should be regarded with caution, as this could in fact lead to misidentification.

\subsubsection{Particularity of prior description}

The SCA acknowledges that the quality of the witness's description of the accused is of vital importance. Where it is rich in specifics, it would carry more weight than a more generic description. In $S v$ Charzen $^{137}$ Cameron $\mathrm{J}$ stated: "[F]acial characteristics are a more reliable and enduring source of identification than variable features such as hairstyle or clothing." 138

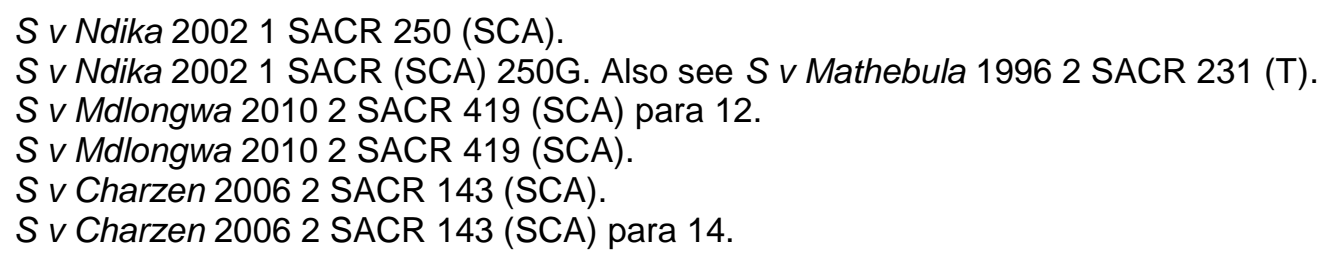


In casu, the only description given of the two convicted persons is the fact that one (the appellant) had very short cut hair and that the other was wearing blue Adidas clothing. How the court a quo and especially the SCA could have found that these descriptions were sufficient to warrant the identification of the accused is problematic. The question arises as to how many other people could have had short cut hair and could have worn blue Adidas clothes? A bold statement that the accused is the person who committed the crime is not adequate. Such a statement, unexplored, untested and uninvestigated, leaves the door open for the possibility of error. ${ }^{139}$

\subsubsection{Identification of familiars or strangers}

It was relevant to determine whether the appellant and Mbatha were previously acquainted. Identifying a person with whom one is acquainted bears a deal of reliability that is absent when identifying a stranger. The appellant was a stranger to Mbatha and the identification should have been approached with more caution. In $S v$ Ramabokela ${ }^{140}$ it was pointed out that while a dock identification might not carry the same weight as evidence arising out of a proper identification parade, it could not be equated to the answer to a leading question. The usual cautionary rule has to be applied, and the weight of the evidence depends on the circumstances of the individual case. In that case the witnesses were found to be honest and reliable, and the fact that one of them knew the appellants beforehand would have rendered the holding of a formal identification parade valueless.

\subsubsection{A dock identification or in-court identification}

A dock identification or in-court identification assumes that the witness correctly observed the accused perpetrating the crime and can reliably identify the perpetrator in court. Where the accused has been identified independently in a prior procedure, such as in an identification parade, the possibility of misidentification is ameliorated to a great extent. In casu this was not the case. In fact, the dock identification came in answer to a direct question of the State; "Are you in a position or are you able to identify any one of them?" A dock identification can be criticized in these two complementary respects: not only does it lack the safeguards that are offered by an identification parade, but the position of the accused persons in the dock positively increases the risk of a wrong identification.

\footnotetext{
$139 S$ V Tandwa 20081 SACR 613 (SCA) para 130.

140 S v Ramabokela 20111 SACR 122 (GNP).
} 
Paragraph 10 states that:

merely because Mbatha made a dock identification of the appellant and accused 5 does not make his evidence less credible.

The court refers to $S \vee$ Tandwa, ${ }^{141}$ where the SCA held that a dock identification carries little weight unless it is shown to be sourced in an independent preceding identification. This would for example be where a prior identification parade has been held. This was not done. In fact, any prior procedure that could vouchsafe for the reliability of the dock identification would generally be taken into consideration. When the court in casu holds that there is no rule of law that a dock identification must be discounted altogether, it merely asserts the law as it stands. ${ }^{142}$ But when the court tries to galvanise the dock identification by stating that the evidence should be accurate, because Mbatha had ample opportunity at least to observe two of the robbers, this is just factually incorrect. The evidence clearly shows that the robbery took two minutes and 10 seconds.

In this regard the court in $S v D e$ Vries $^{143}$ remarked:

It is so that an identification parade is not only an accepted investigative procedure but also serves an important evidential purpose in that it can provide the prosecution with evidence which is of far more persuasive value than an identification in court. See in this regard $R v$ Sebeso 1943 AD 196 and $R v$ Mputing 1960 (1) SA 785 (T) at 788G. ${ }^{144}$

\section{Conclusion}

The law, at times, fails to keep pace with developments in science. In Henderson the court boldly recognised that the legal standards governing the admissibility and use of identification evidence lagged far behind the findings of numerous studies in the social sciences. ${ }^{145}$ The decision reflects the growing awareness that the existing standards in State courts and The

141 S v Tandwa 20081 SACR 613 (SCA).

142 In S v Tandwa 20081 SACR 613 (SCA) it was said by Cameron JA, Mlambo JA and Hancke AJA (at [129]): "Dock identification ... may be relevant evidence, but generally, unless it is shown to be sourced in an independent preceding identification, it carries little weight". In this case the dock identification was held reliable for several reasons, including the fact that the witness concerned had had prior prolonged exposure to the accused and had also paired two of the accused who were shown to have had a close association with each other.

143 S v De Vries (67/2005) [2008] ZAWCHC 36 (10 June 2008).

$144 S$ v De Vries (67/2005) [2008] ZAWCHC 36 (10 June 2008) para [262].

$145 S v$ Henderson 27 A 3d 872 (NJ 2011). 
Supreme Court in the United States evaluating eyewitness testimony set out in Manson v Brathwaite, ${ }^{146}$ are inconsistent with scientific knowledge. ${ }^{147}$

The New Jersey court indicated that revised jury instructions were needed to help jurors "both understand and evaluate the effects that various factors have on memory", ${ }^{148}$ noting that jurors "do not intuitively understand all of the relevant scientific findings". ${ }^{149}$ In the light of Mdlongwa this might also be said about some judges and magistrates in South Africa. The Henderson court concluded that science-based revisions were necessary "because eyewitness identifications bear directly on guilt or innocence". ${ }^{150}$

The Henderson court is emphatic that

\begin{abstract}
[h] uman memory is not foolproof. Research has revealed that human memory is not like a video recording that a witness needs only to replay to remember what happened. Memory is far more complex. The process of remembering consists of three stages: acquisition - the perception of the original event; retention - the period of time that passes between the event and the eventual recollection of a piece of information; and retrieval - the stage during which a person recalls stored information. At each of these stages, memory can be affected by a variety of factors.
\end{abstract}

The main aspects of the complete jury instructions ${ }^{151}$ on eyewitness evidence issued by the New Jersey Supreme Court are that:

- $\quad$ One, whether the witness was under a high level of stress. Even under the best viewing conditions, high levels of stress can reduce an eyewitness's ability to recall and make an accurate identification.

- $\quad$ Two, whether a weapon was used, especially if the crime was of short duration. The presence of a weapon can distract the witness and take the witness's attention away from the perpetrator's face. As a result, the presence of a visible weapon may reduce the reliability of the subsequent identification if the crime is of short duration.

- $\quad$ Three, how much time the witness had to observe the event. Although there is no minimum time required to make an accurate identification, a brief or fleeting contact is less likely to produce an

146 Manson v Brathwaite 432 US 98 (1977).

147 The more recent decision of the Supreme Court of Oregon $S v$ Lawson 352 Or 724 (2012) also reflects this point of view. See Perry v New Hampshire 132 S Ct 716, 730 (2012), discussed below.

$148 S$ v Henderson 27 A 3d 872 (NJ 2011).

$149 S$ v Henderson 27 A 3d 872 (NJ 2011).

$150 S$ v Henderson 27 A 3d 872 (NJ 2011).

151 Criminal Practice Committee 2012 http://bit.ly/21KZq7R. 
accurate identification than a more prolonged exposure to the perpetrator. In addition, time estimates given by a witness may not always be accurate because witnesses tend to think events lasted longer than they actually did.

- $\quad$ Four, whether the witness possessed characteristics that would make it harder to make an identification, such as the age of the witness and the influence of drugs or alcohol. An identification made by a witness under the influence of a high level of alcohol at the time of the incident tends to be more unreliable than an identification by a witness who consumed a small amount of alcohol.

- $\quad$ Five, whether the perpetrator possessed characteristics that would make it harder to make an identification. Was he or she wearing a disguise? Did the suspect have different facial features at the time of the identification The perpetrator's use of a disguise can affect a witness's ability both to remember and identify the perpetrator. Disguises like hats, sunglasses, or masks can reduce the accuracy of an identification. Similarly, if facial features are altered between the time of the event and a later identification procedure, the accuracy of the identification may decrease.

- Six, how much time elapsed between the crime and the identification. Memories fade with time. The more time that passes, the greater the possibility that a witness's memory of a perpetrator will weaken.

- Seven, whether the case involves cross-racial identification. Research has shown that people may have greater difficulty in accurately identifying members of a different race.

- $\quad$ Eight, whether the observation of the perpetrator was close or far. The greater the distance between an eyewitness and a perpetrator, the higher the risk of a mistaken identification. In addition, a witness's estimate of how far he or she was from the perpetrator may not always be accurate because people tend to have difficulty estimating distances.

- Nine, whether or not the lighting was adequate during the observation. Inadequate lighting can reduce the reliability of an identification. 
- $\quad$ Ten, the confidence of the witness, standing alone, may not be an indication of the reliability of the identification. Although some research has found that highly confident witnesses are more likely to make accurate identifications, eyewitness confidence is generally an unreliable indicator of accuracy. Even an identification made in good faith could be mistaken.

In 2012, the Supreme Court of the United States in Perry $v$ New Hampshire ${ }^{152}$ side-stepped the issues concerning the appropriateness of the outmoded reliability standard ${ }^{153}$ of eyewitness evidence. The opportunity was lost to determine the use of scientifically informed criteria appropriately to deal with eyewitness testimony. However, Robert Couch, ${ }^{154}$ commenting on the Perry $v$ New Hampshire case, stated that

Henderson not Perry, is the wave of the future. While Perry remained silent on critical issues, Henderson attacked directly - creating a modern framework to evaluate eyewitness evidence that is in line with the scientific studies of the past thirty-five years.

The fundamental aim of eyewitness identification evidence is reliably to convict the guilty and to protect the innocent. This new wave, introduced by $S v$ Henderson, has not gone unnoticed in other State courts in the USA. In $S v$ Lawson $^{155}$ the court gave recognition to all the factors highlighted in Henderson. Lawson went further and held that the court should take judicial notice of legislative facts of the science of memory. In Massachusetts, the Justices of the Supreme Judicial Court convened a study group on Eyewitness Evidence. ${ }^{156}$ The Report inter alia recommends judicial notice of modern psychological principles, ${ }^{157}$ revised jury eyewitness identification instructions ${ }^{158}$ and continuous education of both judges and lawyers. ${ }^{159}$

152 Perry v New Hampshire 132 S Ct 716, 730 (2012).

153 Couch 2013 Mich L Rev 1535-1548.

154 Couch 2013 Mich L Rev 1545.

$155 S$ v Lawson 352 Or 724, 740 (2012).

156 Supreme Judicial Court Study Group Recommendation 1 at 9.

157 Supreme Judicial Court Study Group Recommendation 4 at 11

158 Supreme Judicial Court Study Group Recommendation 4 at 12.

159 Supreme Judicial Court Study Group Recommendation 4 at 12. National Research Council Identifying the Culprit recognises that the federal standard governing the admissibility of eyewitness testimony as set forth in the Manson $v$ Braithwaite test under the Due Process Clause of the US Constitution was set out in 1977 before much of the applied research on eyewitness identification had been conducted, and it includes factors that are not diagnostic of reliability. It recommends best practices for judges to follow in assessing and using eyewitness testimony, inter alia recommending that judges assessing the reliability of an eyewitness identification should determine which eyewitness identification procedures the police had in place and the degree to which they were followed. The report also emphasis that an eyewitness identification should not typically occur for the first time in a courtroom. 
There is no reason why the scientific principles discussed above should not be applicable to South African law. Recognition and education pertaining to these factors can and should be incorporated in South Africa. This would indeed be science serving justice.

\section{Bibliography}

\section{Literature}

Couch 2013 Mich L Rev

Couch R "A Model for Fixing Identification Evidence after Perry $v$ New Hampshire" 2013 Mich L Rev 1535-1548

Cutler et al 1987 J Appl Psychol

Cutler BL et al "Improving the Reliability of Eyewitness Identification: Putting Context into Context" 1987 J Appl Psychol 629-637

Deffenbacher et al 2004 Law \& Hum Behav

Deffenbacher KD et al"A Meta-Analytic Review of the Effects of High Stress on Eyewitness Memory" 2004 Law \& Hum Behav 687-708

Dysart et al 2002 J Appl Psychol

Dysart JE et al "The Intoxicated Witness: Effects of Alcohol Identification Accuracy from Showups" 2002 J Appl Psychol 170-175

Edmond and Meintjes-Van der Walt 2014 SALJ

Edmond $G$ and Meintjes-Van der Walt $L$ "Blind Justice: Forensic Science and the Use of Closed Circuit Television (CCTV) Images in South Africa" 2014 SALJ 109-148

\section{Epstein 2007 Stetson L Rev}

Epstein $\mathrm{J}$ "The Great Engine that Couldn't: Science, Mistaken Identity, and the Limits of Cross-Examination" 2007 Stetson L Rev 727-785

Findley "Wrongful Conviction"

Findley KA "Wrongful Conviction" in Cutler BL (ed) Encyclopedia of Psychology and Law (SAGE Thousand Oaks 2007) 869-873

Harris Failed Evidence

Harris D Failed Evidence: Why Law Enforcement Resists Science (New York University Publishers New York 2012)

Leippe 1995 Psychol Pub Pol'y \& L 
Leippe M "The Case for Expert Testimony about Eyewitness Memory" 1995 Psychol Pub Pol'y \& L 909-959

Lindsay et al 2008 Law \& Hum Behav

Lindsay RCL et al "How Variations in Distance Affect Eyewitness Reports Identification Accuracy" 2008 Law \& Hum Behav 526-535

Loftus Eyewitness Testimony

Loftus EF Eyewitness Testimony $2^{\text {nd }}$ ed (Harvard University Press Cambridge, Mass 1996)

Loftus et al 1987 Appl Cogn Psychol

Loftus EF et al "Time Went by So Slowly: Overestimation of Event Duration by Males and Females" 1987 Appl Cogn Psychol 3-13

Maass and Köhnken 1987 Law \& Hum Behav

Maass A and Köhnken G "Eyewitness Identification: Simulating the 'Weapon Effect'" 1987 Law \& Hum Behav 397-408

Meintjes-Van der Walt 2009 SACJ

Meintjes-Van der Walt $L$ "Eyewitness Evidence and Eyewitness Science: Whether the Twain Shall Meet?" 2009 SACJ 305-326

Morgan et al 2004 Int'l J L \& Psychiatry

Morgan CA et al "Accuracy of Eyewitness Memory for Persons Encountered During Exposure to Highly Intense Stress" 2004 Int'l J L \& Psychiatry 265279

Münsterberg On the Witness Stand

Münsterberg H On the Witness Stand (Doubleday New York 1908)

National Research Council Identifying the Culprit

National Research Council Identifying the Culprit: Assessing Eyewitness Identification (National Academies Press Washington DC 2014)

Patterson and Baddeley 1977 J Exp Psychol Hum Learn Mem

Patterson KE and Baddeley AD "When Face Recognition Fails" 1977 J Exp Psychol Hum Learn Mem 406-417

Penrod and Cutler 1995 Behav Sci \& L

Penrod S and Cutler B "Expert Psychological Testimony on Eyewitness Reliability Before and After Daubert: The State of the Law and Science" 1995 Behav Sci \& L 229-256 
Pickel "Remembering and Identifying Menacing Perpetrators"

Pickel KL "Remembering and Identifying Menacing Perpetrators: Exposure to Violence and the Weapon Focus Effect" in Lindsay RCL et al (eds) The Handbook of Eyewitness Psychology: Memory for People (Lawrence Erlbaum Mahwah, NJ 2007) 339-360

Pozzulo and Lindsay 1998 Law \& Hum Behav

Pozzulo JD and Lindsay RCL "Identification, Accuracy of Children Versus Adults: A Meta-Analysis" 1998 Law \& Hum Behav 549-570

Shell 2013 Suffolk U L Rev

Shell EG "Recipe for Mistaken Convictions: Why Federal Rule of Evidence 403 Should Be Used to Exclude Unreliable Eyewitness-Identification Evidence. A Note" 2013 Suffolk U L Rev 263-287

Skeen 1987 SALJ

Skeen A St Q "Eyewitness Evidence and Psychology" 1987 SALJ 297-305

Steblay 1992 Law \& Hum Behav

Steblay N "A Meta-Analytic Review of the Weapon Focus Effect" 1992 Law \& Hum Behav 413-425

Tredoux "Eyewitness Identification"

Tredoux CG "Eyewitness Identification" in Spielberger CD (ed) Encyclopedia of Applied Psychology (Elsevier Academic Press Oxford 2004) $875-887$

Wells $1978 \mathrm{~J}$ Pers Soc Psychol

Wells GL "Applied Eyewitness-Testimony Research: System Variables and Estimator Variables" 1978 J Pers Soc Psychol 1546-1557

Wells, Memon and Penrod 2006 Psychol Sci Public Interest Wells GL, Memon A and Penrod SD "Eyewitness Evidence Improving Its Probative Value" 2006 Psychol Sci Public Interest 45-75

Wyss Visual Identification

Wyss K Visual Identification: Is the Current Law Sufficient to Protect against Misidentification? (LLB-dissertation University of Otago 2011)

\section{Case law}

\section{South Africa}

Holtzhausen $v$ Roodt 19974 SA 766 (WLD) 
$R v$ Masemang 19502 SA 488 (A)

$R v$ Mokoena 1932 OPD 79

$R v$ Mputing $19601 \mathrm{SA} 785$ (T)

S v Charzen 20062 SACR 143 (SCA)

$S v$ de Vries (67/2005) [2008] ZAWCHC 36 (10 June 2008)

S v Engelbrecht 20052 SACR 41 (W)

S v Mathebula 19962 SACR 231 (T)

S v Mdlongwa 20102 SACR 419 (SCA)

S v Mthetwa 19723 SA $766(\mathrm{~A})$

S v Ndika 20021 SACR 250 (SCA)

$S v$ Ngobo 19861 SA $905(\mathrm{~N})$

S v Ramabokela 20111 SACR 122 (GNP)

S v Tandwa 20081 SACR 613 (SCA)

Trial transcript Record of Appeal Vol 1

Trial transcript Record of Appeal $S \vee$ Mdlongwa Appeal Court case AR 395/06 Regional Court Case RC 96/2004 Vol 1

Trial transcript Record of Appeal Vol 7

Trial transcript Record of Appeal S Mdlongwa Appeal Court case AR 395/06 Regional Court Case RC 96/2004 Vol 7

\section{United States of America}

Manson v Brathwaite 432 US 98 (1977)

Perry v New Hampshire 132 S Ct 716 (2012)

S v Guilbert 306 Conn 218 (2012)

S v Henderson 27 A 3d 872 (NJ 2011) 
S v Lawson 352 Or 724 (2012)

S v Madison 109 NJ 223, 536 A 2d 254 (1988)

\section{Internet sources}

Criminal Practice Committee 2012 http://bit.ly/21KZq7R

Criminal Practice Committee 2012 Revised Jury Instructions http://bit.ly/21KZq7R accessed 13 January 2015

FARLEX 2014 http://bit.ly/1XfviB3

FARLEX 2014 The Free Dictionary: Special Master http://bit.ly/1XfviB3 accessed 13 March 2014

Monroe $2013 \mathrm{http}: / /$ bit.ly/1TwThG0

Monroe K 2013 Understanding Crime Victim Perspectives on Wrongful Convictions http://bit.ly/1TwThG0 accessed 10 July 2014

Supreme Court of New Jersey 2008 http://bit.ly/1VP6ikK

Supreme Court of New Jersey 2008 State of New Jersey $v$ Henderson: Report of the Special Master http://bit.ly/1VP6ikK accessed 13 March 2014

Supreme Judicial Court Study Group

Supreme Judicial Court Study Group on Eyewitness Evidence 2013 Report and Recommendations http://www.mass.gov/courts/docs/sjc/docs/ eyewitness-evidence-report-2013.pdf accessed on 11 May 2016

\section{List of Abbreviations}

\begin{tabular}{|c|c|}
\hline Appl Cogn Psychol & Applied Cognitive Psychology \\
\hline Behav Sci \& L & Behavioral Science and Law \\
\hline Bull Psychon Soc & Bulletin of the Psychonomic Society \\
\hline Cogn Psychol & Cognitive Psychology \\
\hline Int'I J L \& Psychiatry & $\begin{array}{l}\text { International Journal of Law and } \\
\text { Psychiatry }\end{array}$ \\
\hline J Appl Psychol & Journal of Applied Psychology \\
\hline J Exp Psychol Hum Learn Mem & $\begin{array}{l}\text { Journal of Experimental Psychology: } \\
\text { Human Learning and Memory }\end{array}$ \\
\hline J Pers Soc Psychol & $\begin{array}{l}\text { Journal of Personality and Social } \\
\text { Psychology }\end{array}$ \\
\hline Law \& Hum E & Law and Human Behavior \\
\hline Mich L Rev & Michigan Law Review \\
\hline
\end{tabular}


Psychol Bull

Psychol Pub Pol'y \& L

Psychol Sci Public Interest

SACJ

SALJ

Stetson L Rev

Suffolk U L Rev
Psychological Bulletin

Psychology, Public Policy and Law

Psychological Science in the Public Interest

South African Journal of Criminal Justice

South African Law Journal

Stetson Law Review

Suffolk University Law Review 